Journal of Sustainable Agricultural Sciences

\title{
New Pollution Challenges in Groundwater and Wastewater Due to COVID-19
}

\author{
Hassan El-Ramady ${ }^{1}$, Yahya Eid ${ }^{2}$ and Eric C. Brevik ${ }^{3 *}$ \\ ${ }^{I}$ Soil and Water Dept., Faculty of Agriculture, Kafrelsheikh University, 33516 Kafr \\ El-Sheikh, Egypt \\ ${ }^{2}$ Poultry Dept., Faculty of Agriculture, Kafrelsheikh University, 33516 Kafr El-Sheikh, \\ Egypt \\ ${ }^{3}$ Departments of Natural Sciences and Agriculture and Technical Studies, Dickinson \\ State University, Dickinson, ND 58601, USA
}

\section{Table of contents}

1. Introduction

2. Aquatic environments and their pollution

3. Polluted groundwater and COVID-19

4. COVID-19 and polluted wastewater

5. Conclusion

Acknowledgement

6. References

\begin{abstract}
W ATER is considered one of the most important components of life, alongside atmospheric air. Its pollution represents a serious threat not only to human health but also to the surrounding ecology. Water pollution problems were aggravated in the era of COVID-19. Approximately $80 \%$ of global diseases are waterborne, and polluted aquatic environments have been linked to the SARS-CoV-2 virus, which causes the disease COVID-19. Understanding the fate of this virus in aquatic environments like water and wastewater is critical. SARS$\mathrm{CoV}-2$ may be adsorbed on charged colloidal particles and this process probably depends on the $\mathrm{pH}$ of the medium. Other parameters that may influence this process include sorptive interaction with solid particles in soils, aquatic environments and sewage sludge. There are several areas of research that need to be investigated regarding the relationship between SARS-CoV-2 and the transmission of COVID-19 to aqueous environments, including indirect relationships between different aquatic environments (e.g., groundwater, drinking water and wastewater) and outbreaks of COVID-19. Different pathways and the fate of SARS-CoV-2 in water, wastewater and groundwater and subsequent human exposures also need to be determined. These issues will be explored in this review.
\end{abstract}

Keywords: Environmental pollution; Coronavirus; SARS-CoV-2; Groundwater; Drinking water; Human health; Disease

\section{Introduction}

The global coronavirus disease 2019 (COVID-19), a disease caused by the severe acute respiratory syndrome coronavirus (SARS-CoV-2), represents a great challenge for countries worldwide (Wang and $\mathrm{Su}$ 2020). Habib et al. (2021) stated "The way the COVID-19 pandemic has halted normal life has no precedent in modern history". This pandemic is probably one of the worst to face humanity in modern history due to the high death toll, interruptions in human activities and negative impacts on the global economy when compared to other pandemics like HIV, polio, Spain flu, severe acute respiratory syndrome (SARS), the Middle East respiratory syndrome (MERS), and Ebola

"Corresponding author: E-mail: eric.brevik@dickinsonstate.edu 
(Saqr and Wasson 2020). The environmentally destructive impacts of COVID-19 have been recorded in important life sectors such as food security, agriculture, and livelihoods (Lal et al. 2020; Workie et al. 2020), animal health (Gortázar and de la Fuente 2020), air pollution (El-Ramady et al. 2020; Mostafa et al. 2021), energy domains (Mofijur et al. 2021), solid wastes (Urban et al. 2021), NOx emissions (He et al. 2021), food-energy-water-waste nexus (Zhao and You, 2021), the global economy and ecosystems (Ibn-Mohammed et al. 2021), global metal supply (Habib et al. 2021), forest fires (Paudel, 2021), food wastes (Brizi and Biraglia, 2021), energy grid dynamics (Werth et al. 2021) and the entire environment (Espejo et al. 2020; Lokhandwala and Gautam 2020; Juan-Reyes et al. 2021).

Pollution is considered a serious challenge facing the whole world, particularly in developing countries (Verma, 2020). Due to intensive anthropogenic activities, several deleterious effects on the environment, including aquatic systems, and its resources have occurred (Siddiqa and Faisal, 2020). The freshwater ecosystem includes aquatic habitats that are highly prone to pollution due to the intensive interactions between these habitats and humans (Verma, 2020). Heavy metals (HMs) are of special concern, being important inorganic pollutants that cause many problems through their toxicity as well as being non-degradable and therefore persistent in nature (Aitta et al. 2019; Verma 2020). The presence of organic pollutants and pathogens can also cause major problems (Brevik et al. 2020). These pollutants, when present in aquatic environments, may have negative implications for cultivated plants, domesticated animals, humans and the food chain (Yan et al. 2019).

One of the major water quality issues of our day is the COVID-19 pandemic (Fig.1). More than 200 countries worldwide have engaged in the fight against COVID-19 since January 2020. This struggle has become the top priority in many of these countries. Thus, the scientific community has published over a million articles (according to Google Scholar, searching "COVID 19 " on November 26, 2020) on COVID-19. These studies have covered a wide range of COVID-19 topics, with focus on the perspectives of different disciplines such as medicine, biology, tourism, socioeconomics and environmental studies (Casado-Aranda et al. 2020). Torres-Salinas (2020) reported that the number of scientific articles on COVID-19 have doubled every 15 days since the pandemic's outset. A pressing question involving the COVID-19 outbreak is whether aquatic environments have direct or indirect roles in spreading this disease, and if they do, under

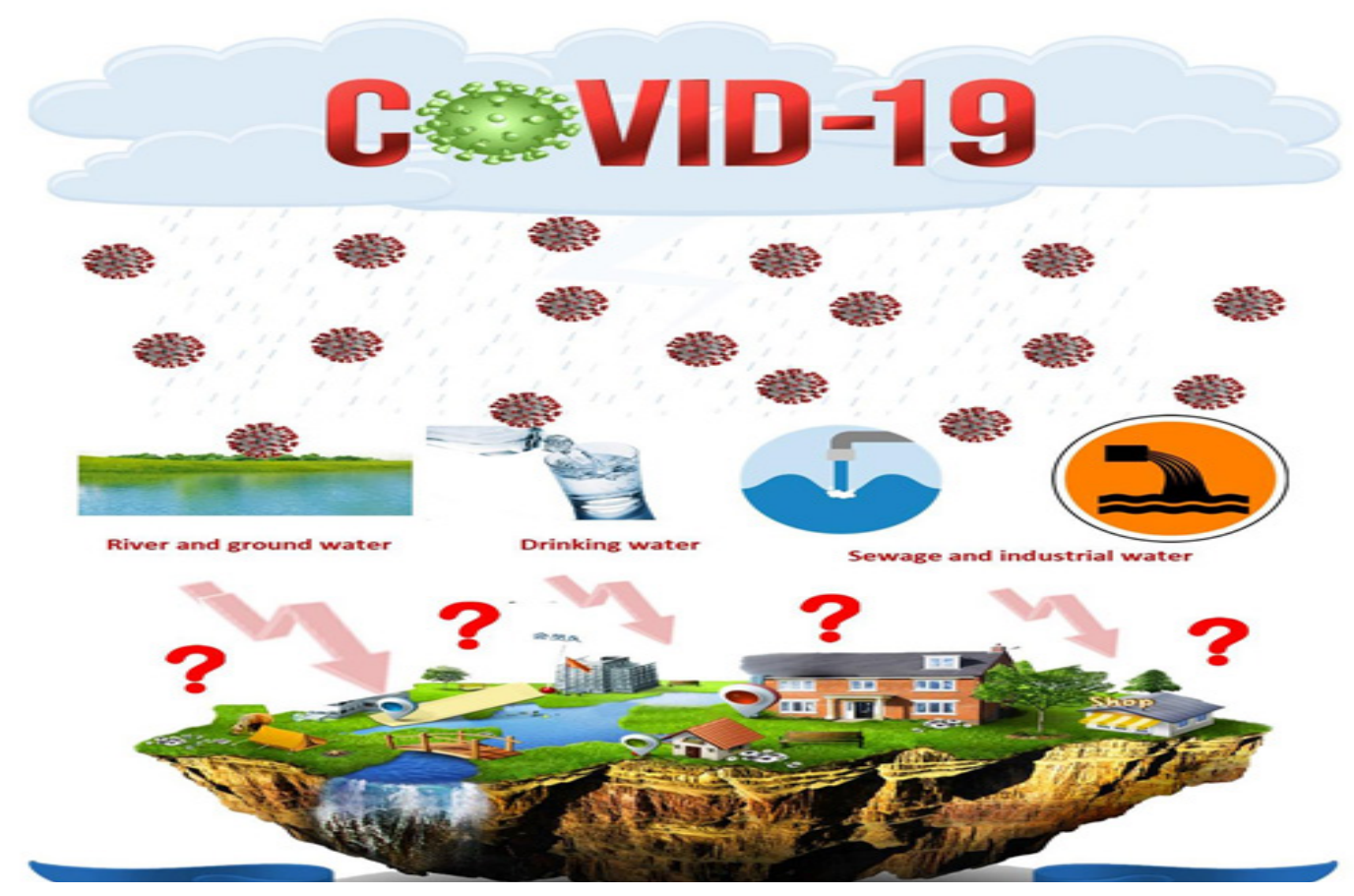

Fig. 1. A summary of selected major aquatic challenges related to COVID-19. These challenges may include the transmission of COVID-19 to groundwater or from the wastewater to different sources of water like drinking water or to the human. Several confirmations concerning this transmission among water resources still are needed 
what conditions? Few studies have addressed this problem (Kumar et al. 2020a). Therefore, this work investigated the potential relationship between polluted wastewater and COVID-19 and its impact on aquatic environments.

\section{Aquatic environments and their pollution}

Water is the main source of life; without water life as we know it would not exist. Aquatic environments occupy more than $70 \%$ of Earth's surface, including oceans, rivers, lakes, wetlands, and springs ( $\mathrm{Li}$ et al. 2020). These aquatic environments may suffer from pollution due to intensive human activities, which may increasingly result in the deterioration of food chains and, ultimately, deterioration of the aquatic life cycle. The three main sources of water pollution are urban wastewater, agricultural development, and industrial effluents (Kiani and Rahimpour 2020). Polluted aquatic environments are considered a human health threat that cause a lot of environmental problems (e.g., Martins et al. 2014; Farkas et al. 2020; Kiani and Rahimpour, 2020). This pollution has been monitored and assessed by researchers in a plethora of studies including occurrence, detection methods, fate, ecological toxicity and removal methods (Li et al. 2020). Several approaches have been adapted to decontaminate polluted aquatic environments from HMs and organic pollutants (Ajiboye et al. 2021) using techniques such as biochar (Yang et al. 2021), nano zero valent iron (Sliječpević et al. 2021), and clays (Elshazly et al. 2019). Other pollutants may cause serious threats to human health and ecosystems when they reach aquatic environments, including nanoparticles (Turan et al. 2019; Souza et al. 2021), antibiotics (Li et al. 2020; Xu et al. 2021), microplastics (Ma et al. 2020; Tang et al. 2020; Pan et al. 2021; Wang et al. 2021), bisphenols (Liu et al. 2021; Šauer et al. 2021), retinoic acids (Yeung et al. 2020), perfluoroalkylated acids (Groffen et al. 2021), heavy metals (Aitta et al. 2019; Karaouzas et al. 2021), personal care products (Zhou et al. 2020; Lu et al. 2021), antineoplastic agents (Yadav et al. 2021) and COVID-19 (Kumar et al. 2020a; Steffan et al. 2020; Lachrich et al. 2021). On the other hand, during lockdowns to combat COVID-19, the quality of surface water (Yunus et al. 2020) and air (Guatam, 2020) are expected to improve.

\section{Polluted groundwater and COVID-19}

Water scarcity is a major global issue, particularly in arid and semi-arid regions. Preserving sources of clean and safe drinking water is critical for nations all over the world. Groundwater is the main source of drinking and irrigation water in many countries (Cai et al. 2020) and is important in sustaining native terrestrial ecosystems (Huang et al. 2019). In general, groundwater-dependent ecosystems are divided into three types based on their ecological function: (1) aquifers and cave ecosystems, (2) wetlands, springs, rivers, estuaries and nearshore marine ecosystems and (3) terrestrial vegetation ecosystems (Huang et al. 2019). Due to global climate changes, which includes increasing temperatures and redistribution of precipitation, groundwater recharge has decreased in many places while salinity has increased (El-Ramady et al. 2017, 2019). Groundwater pollution problems have gained global attention in recent decades due to their frequent occurrence and potentially adverse effects on aquatic ecosystems and human health (Kuroda and Kobayashi 2021). Many studies have focused on the pollution of groundwater and its remediation (e.g., Haris et al. 2020), which may depend on advanced technologies and its sustainability. Recent reports that address these issues include:

1- A global review on pollution of domestic groundwater systems by verotoxigenic Escherichia coli (Chique et al. 2021),

2- Global sources of groundwater and their security as well as scarcity and sustainability issues (Mukherjee et al. 2021). These issues are being documented in many countries, such as Australia (Maheshwari 2021), Bangladesh (Ahmed 2021), Brazil (Sahoo et al. 2021), China (Huang et al. 2021; Jia 2021), Pakistan (Masood et al. 2021), and the USA (Schreiber 2021),

3- Groundwater pollution in Japan as a result of the Kumamoto earthquakes in 2016; artificial sweeteners and acesulfame were used as tracers to evaluate sewer exfiltration to groundwater (Ishii et al. 2021),

4- Investigating multi-isotopic and molecular source tracking methods in nitrate pollution identification in groundwater based on the 91/676/CEE regulation of the European Nitrate Directive (Carrey et al. 2021),

5- Studying the health risks posed by groundwater polluted with various nitrogen forms (nitrate, nitrite and ammonium) (Adimalla and Qian 2021; Cameira et al. 2021; Wu et al. 2021; Li et al. 2021),

J. Sus. Agric. Sci. Vol. 46, No. 4 (2020) 
6-Assessing the public health risks associated with the geochemical evolution of groundwater polluted with nitrate and fluoride (Nawale et al. 2021),

7- Investigating the effects of drought on the environmental health risks posed by polluted groundwater, including both cancerogenic and non-cancerogenic threats (Kubicz et al. 2021),

8- Assessing pesticides and nitrogen pollution sources using stable isotopes in a complex multi-stressed catchment. Nitrate in groundwater may result totally or partially from $\mathrm{NH}_{4}^{+}$- mineralization and nitrification from organic sources (i.e., manure or sewage sludge) or may originate from inorganic fertilizers (Postigo et al. 2021),

9- Studying the hazardous effects of microplastics in natural water resources. Effects were found to depend on the sources, origins, pathways and receptors of the microplastics (Selvam et al. 2021),

10- Studying polyfluoroalkyl substances in groundwater to understand their occurrence, sources and related health risks (Zhou et al. 2021),

11-Investigating groundwater-dependent ecosystems as transfer vectors of nitrogen from groundwater to surface waters in agricultural basins (Balestrini et al. 2021) and

12- Assessing how the use of plastic in farming processes may affect water quality; accordingly, aquifers and drinking water supplies should be protected from plastic and pesticide contaminants and thus reduce potential human health hazards (Wanner, 2021).

On the other hand, very few studies have been published concerning COVID-19 and groundwater. Patni and Jindal (2020), Núñez-Delgado (2020), and Steffan et al. (2020) addressed potential indirect impacts of COVID-19 on groundwater. Patni and Jindal (2020) presented potential positive impacts. More precisely, Patni and Jindal 2020 found that groundwater stores increased and quality improved during the COVID-19 pandemic due to the reduction of many human activities. Núñez-Delgado (2020) and Steffan et al. (2020) both noted potential negative impacts of COVID-19 on the groundwater system, primarily the introduction of the SARS-CoV-2 viral pathogen into groundwater through contaminated wastewater. There are several open questions concerning the relationship between groundwater and COVID-19, such as what are the direct and indirect impacts of COVID-19 on the global groundwater resource? Does groundwater play any role in propagating the COVID-19 pandemic? What are the positive and negative impacts of COVID-19 on global groundwater? And how much protection does the overlying soil "filter" provide groundwater against contamination with SARS-CoV-2?

\section{COVID-19 and polluted wastewater}

Wastewater is defined as "all the water from homes and urban public facilities like hospitals, schools, and others as well as from certain industries if it does not require specific treatment" (Lahrich et al. 2021). Wastewater may be a source of pathogens, as occurs in hospital effluents and household sewage. Nearly $80 \%$ of global human diseases are waterborne according to WHO. Unhygienic water is attributed to approximately 1.5-12 million deaths per year due to waterborne diseases such as cholera, diarrhea, typhoid, and viral hepatitis (Bhatt et al. 2020). Lethal viral diseases include hepatitis, gastroenteritis, and respiratory illnesses like the present COVID-19 pandemic, which is caused by SARS-CoV-2 (Cao 2020). The presence of COVID-19 in wastewater has been demonstrated by recent studies (Mallapaty 2020; Lodder and Husman 2020; Ahmed et al. 2020; Wu et al. 2020; Bhatt et al. 2020). It has been suggested that both surface and groundwater represent SARS-CoV-2 control points through addition of effluents and possible contamination from health care facilities, sewage and drainage water (Kumar et al. 2020a). Therefore, the different possible transmission pathways of SARS-CoV-2 to water sources should be identified to prevent further rapid spread of such a disease (Bhatt et al. 2020). SARS-CoV-2 may enter water bodies through different routes such as feces, sewage and on surfaces according to WHO. Because SARSCoV-2 is known to transmit through the air and has been found in water sources, the possibility that COVID-19 could be spread through both aquatic and non-aquatic environments needs to be strongly considered (Bhatt et al. 2020).

Several investigations have addressed the fate and transmission of COVID-19 in wastewater, important topics covered include: 
1- Emphasis on detection methods and prevalence of the SARS-CoV-2 virus in wastewater (Lahrich et al. 2021),

2- The role of water, sanitation and hygiene in spreading COVID-19 through the fecal-oral route, particularly in low-income countries (Table 1). The spread of COVID-19 is currently premised on respiratory and contact transmission; however, a fecal-oral pathway has been suggested for the transmission of SARS-CoV-2 from the human gut to stools and wastewater (Bhatt et al. 2020; Gwenzi 2021),

3- The occurrence and persistence of SARS$\mathrm{CoV}-2$ in the environments and conditions favorable for the survival of this virus in water/wastewater/sewage has not yet been established, despite evidence of the transmission of the infective virus to the community (Ihsanullah et al. 2020; Mohan et al. 2021),
4- Potential secondary transmission of SARSCoV-2 via wastewater; reducing risks of transmission could contribute to limiting COVID-19 resurgence and future research should focus on the virus in different aquatic environments (Liu et al. 2020),

5- Implications for SARS-CoV-2 in river water in countries that do not have good sanitation; including important viral loads of SARSCoV-2 from urban streams and how the degree of wastewater treatment may affect COVID-19 risks (Guerrero-Latorre et al. 2020),

6- SARS-CoV-2 surveillance using wastewaterbased epidemiology can be an effective technique in the early detection of COVID-19 within a population, but an effective concentration method is needed for recovery of SARS-CoV-2 RNA from wastewater (Al Huraimel et al. 2020; Bhatt et al. 2020; Corpuz et al.2020; Kitajima 2020),

TABLE 1. A survey on the detection and transmission of COVID-19 through wastewater in different countries

\begin{tabular}{|c|c|c|}
\hline Country/ region & COVID-19 and wastewater & Reference \\
\hline Canada & $\begin{array}{l}\text { The first study and detection of COVID-19 trends in wastewater in Canada. Provided a } \\
\text { quantitative analysis of this virus from wastewater solids during low incidence of viral } \\
\text { load. }\end{array}$ & D’Aoust et al. (2021) \\
\hline Global study & $\begin{array}{l}\text { Hand hygiene could protect from the transmission of COVID-19 via the fecal-oral route. } \\
\text { Viral occurrence in wastewater can estimate its ability to spread. }\end{array}$ & Elsamadony et al. (2021) \\
\hline China & $\begin{array}{l}\text { Studied the potential modes of COVID-19 transmission in health care facilities, which } \\
\text { occur via multiple routes like potential fecal-oral transmission in the toilet and in sewage } \\
\text { pipes. }\end{array}$ & Feng et al. (2021) \\
\hline Global study & $\begin{array}{l}\text { SARS-CoV-2 transmission could potentially be linked to wastewater and biomedical } \\
\text { wastewater disposal risks; this creates a widespread public concern. }\end{array}$ & Kataki et al. (2021) \\
\hline Global study & Wastewater irrigation systems may have a high risk of COVID-19 transmission. & Lahrich et al. (2021) \\
\hline Global study & $\begin{array}{l}\text { The occurrence of COVID-19 has been shown in stool samples from symptomatic and } \\
\text { asymptomatic people as well as in municipal wastewaters worldwide. }\end{array}$ & Langone et al. (2021) \\
\hline Italy & $\begin{array}{l}\text { COVID-19 was already circulating in northern Italy at the end of } 2019 \text {; wastewater } \\
\text { (sewage) monitoring could contribute to the early detection of this viral circulation. }\end{array}$ & La Rosa et al. (2021) \\
\hline Global study & $\begin{array}{l}\text { COVID-19 in wastewater treatment, sanitation status and health-care infrastructure from } \\
\text { middle- and low-income countries was correlated with risk associated with the fecal-oral } \\
\text { transmission route. }\end{array}$ & Pandey et al. (2021) \\
\hline Sweden & $\begin{array}{l}\text { COVID-19 was detected in wastewater treatment plants and was correlated to hospitalized } \\
\text { patients. }\end{array}$ & Saguti et al. (2021) \\
\hline Africa & $\begin{array}{l}\text { SARS-CoV-2 can transmit in water systems (mainly wastewater) and could potentially be } \\
\text { removed by integrating chlorination, ozonation, } \mathrm{UV} \text { irradiation, and } \mathrm{NaClO} \text { treatment techniques. }\end{array}$ & Sunkari et al. (2021) \\
\hline Germany & $\begin{array}{l}\text { The first investigation that reported the detection of COVID-19 in wastewater (wastewater } \\
\text { treatment plants) was in Germany using RT-qPCR. }\end{array}$ & Westhaus et al. (2021) \\
\hline Brazil & $\begin{array}{l}\text { The first study that investigated the potential health risks of SARS-CoV- } 2 \text { in sewage to } \\
\text { wastewater treatment plant workers; the dose of this virus was estimated in workers whose } \\
\text { were exposed during their job. }\end{array}$ & Zaneti et al. (2021) \\
\hline Japan & SARS-CoV-2 was detected in wastewater samples collected from wastewater treatment plants. & Hata et al. (2020) \\
\hline Global study & $\begin{array}{l}\text { There is a possibility for SARS-CoV-2 to become widespread through the wastewater } \\
\text { network. }\end{array}$ & Naddeo and Liu (2020) \\
\hline
\end{tabular}


7- The seasonality of SARS-CoV-2 and its environmental fate, transport, inactivation and antiviral drug resistance issues; wastewater treatment plants are the main reservoirs of antiviral drugs; SARS-CoV-2 may be transmitted as a fecal virus in wastewater, water and groundwater, leading to human exposure (Kumar et al. 2020b), and

8- Environmental conditions that allow the transmission of SARS-CoV-2; humidity and temperature may control viability and survival of SARS-CoV-2 in droplets; the fecal-oral route may be a possible transmission route of COVID-19 from contaminated water bodies; while chlorination may not effectively and completely inactivate SARS-CoV-2 (Mohapatra et al. 2020).

Based on the research completed to date, two main aspects should be considered to control the fate of SARS-CoV-2, including survival and migration, in aquatic environments. One is the structure of the virus; enveloped viruses like SARS-CoV-2 may have significant mobility in sub-surface systems (e.g., groundwater). The second is the transport mechanism and its pathways affecting the water source and its interactions with soil properties such infiltration rate, soil $\mathrm{pH}$, ionic strength, and the adsorption of viruses onto the sub-surface system, all factors in establishing the soil "filter" that protects groundwater systems from contamination. (Kumar et al. 2020a).

\section{Conclusions}

A terrible struggle was initiated in January 2020, and combatting the SARS-CoV-2 virus became a top priority for more than 200 countries. The COVID-19 pandemic has put massive stress on many societal sectors including public administration and information, health care personnel, and the agricultural and industrial sectors. Because several viral diseases are water borne, COVID-19 may well be capable of transmission through aquatic environments. The presence of SARS-CoV-2 in systems such as wastewater has already been established, but further research is needed concerning the fate and transmission of SARS-CoV-2 in water systems. Pressing questions include: Is the water-based transmission of COVID-19 possible? How can the occurrence of SARS-CoV-2 in wastewater be minimized? What about the risks of transmission of COVID-19 in drinking water and its distribution systems? How much protection against SARSCoV-2 does the soil "filter" give to groundwater?
There are several challenges facing the world in addressing aquatic environments and their relationship with COVID-19. Will lockdowns cause by the COVID-19 pandemic help in solving environmental problems like air and water pollution? Or will it aggravate these problems in the future? Questions and problems such as those discussed in this paper represent a serious challenge for all countries, but most particularly for developing countries. The most important question for developing countries is how to support and finance their water and sanitation systems to protect their citizens?

\section{Ethics approval and consent to participate}

This article does not contain any studies with human participants or animals performed by any of the authors.

\section{Consent for publication}

All authors declare their consent for publication.

\section{Contribution of authors}

This study was designed and implemented by all the authors, where all contributed to writing the manuscript, interpreting information presented and have read and agreed to the final version of the manuscript.

\section{Funding}

This research received no external funding.

\section{Conflicts of Interest}

The authors declare no conflict of interest.

\section{Acknowledgement}

The authors thank all the staff members in the Soil and Water Dept., Faculty of Agriculture, Kafrelsheikh University and the Soil Fertility and Plant Nutrition Lab, Soil and Water Dept., Faculty of Agriculture, Kafrelsheikh University for their help with and support of this work.

\section{$\underline{\text { References }}$}

Adimalla N, Qian H (2021) Groundwater chemistry, distribution and potential health risk appraisal of nitrate enriched groundwater: A case study from the semi-urban region of South India. Ecotoxicology and Environmental Safety 207, 111277. https://doi. org/10.1016/j.ecoenv.2020.111277.

Ahmed KM (2021) Bangladesh Challenges of sustainable groundwater development and management in Bangladesh: vision 2050. In: Mukherjee A, et al. (Ed.), Global Groundwater: 
Source, Scarcity, Sustainability, Security, and Solutions. DOI: https://doi.org/10.1016/B978-012-818172-0.00031-1, pp: 425-438. Elsevier Inc.

Ahmed W, Angel N, Edson J, Bibby K, Bivins A, O'Brien JW, Choi PM, Kitajima M, Simpson SL, Li J, Tscharke B, Verhagen R, Smith WJM, Zaugg J, Dierens L, Hugenholtz P, Thomas KV, Mueller JF (2020) First confirmed detection of SARS-CoV-2 in untreated wastewater in Australia: a proof of concept for the wastewater surveillance of COVID-19 in the community. Sci. Total Environ. 138764, https://doi. org/10.1016/j.scitotenv.2020.138764.

Aitta A, El-Ramady H, Alshaal T, El-Henawy A, Shams M, Talha N, Elbehiry F, Brevik EC (2019) Seasonal and spatial distribution of soil trace elements around Kitchener Drain in the northern Nile Delta, Egypt. Agriculture, 9, 152. https://doi.org/10.3390/ agriculture 9070152.

Ajiboye TO, Oyewo OA, DC Onwudiwe (2021) Simultaneous removal of organics and heavy metals from industrial wastewater: A review. Chemosphere, 262, 128379. https://doi. org/10.1016/j. chemosphere. 2020.128379.

Al Huraimel K, Alhosani M, Kunhabdulla S, Stietiya MH (2020) SARS-CoV-2 in the environment: Modes of transmission, early detection and potential role of pollutions. Science of the Total Environment 744, 140946. https://doi.org/10.1016/j.scitotenv. 2020. 140946.

Balestrini R, Delconte CA, Sacchi E, Buffagn A (2021) Groundwater-dependent ecosystems as transfer vectors of nitrogen from the aquifer to surface waters in agricultural basins: The fontanili of the Po Plain (Italy). Science of the Total Environment, 753, 141995. https://doi.org/10.1016/j.scitotenv. 2020. 141995.

Bhatt A, Arora P, Prajapati SK (2020) Occurrence, fates and potential treatment approaches for removal of viruses from wastewater: A review with emphasis on SARS-CoV-2. Journal of Environmental Chemical Engineering, 8, 104429. https://doi. org/10.1016/j.jece. 2020.104429.

Brevik EC, Slaughter L, Singh BR, Steffan JJ, Collier D, Barnhart P, Pereira P (2020) Soil and human health: current status and future needs. Air, Soil, and Water Research, 13, 1-23. https://doi. org/10.1177/1178622120934441.

Brizi A, Biraglia A (2021) "Do I have enough food?" How need for cognitive closure and gender impact stockpiling and food waste during the COVID-19 pandemic: A cross-national study in India and the United States of America. Personality and Individual Differences, 168, 110396. https://doi. org/10.1016/j.paid.2020.110396.

Cai Z, Zhao X, Duan J, Zhao D, Dang Z, Lin Z (2020) Remediation of soil and groundwater contaminated with organic chemicals using stabilized nanoparticles: Lessons from the past two decades. Front. Environ. Sci. Eng. 14 (5), 84 https://doi. org/10.1007/s11783-020-1263-8.

Cameira MR, Rolim J, Valente F, Mesquita M, Dragosits U, Cordovil CMS (2021) Translating the agricultural $\mathrm{N}$ surplus hazard into groundwater pollution risk: Implications for effectiveness of mitigation measures in nitrate vulnerable zones. Agriculture, Ecosystems and Environment, 306, 107204. https:// doi.org/10.1016/j.agee.2020.107204.

Cao X (2020) COVID-19: immunopathology and its implications for therapy, Nat. Rev. Immunol. 20, 269-270,https://doi.org/10.1038/s41577-020-03083.

Carrey R, Ballesté E, Blanch AR, Lucena F, Pons P, López JM, Rull M, Solàc J, Micola N, Fraile J, Garrido T, Munné A, Soler A, Otero N (2021) Combining multi-isotopic and molecular source tracking methods to identify nitrate pollution sources in surface and groundwater. Water Research, 188, 116537. https://doi.org/10.1016/j. watres. 2020. 116537.

Casado-Aranda L-A, Sanchez-Fernandez J, Viedmadel-Jesús MI (2020) Analysis of the scientific production of the effect of COVID-19 on the environment: A bibliometric study. Environmental Research, https://doi.org/10.1016/j.envres. 2020. 110416.

Chique C, Hynds P, Burke LP, Morris D, Ryan MP, O'Dwyer J (2021) Contamination of domestic groundwater systems by verotoxigenic escherichia coli (VTEC), 2003-2019: A global scoping review. Water Research, 188, 116496. https://doi. org/10.1016/j.watres.2020.116496.

Corpuz MVA, Buonerba A, Vigliotta G, Zarra T, Ballesteros FJ, Campiglia P, Belgiorno V, Korshin G, Naddeo V (2020) Viruses in wastewater: occurrence, abundance and detection methods. Science of the Total Environment, 745, 140910. https://doi.org/10.1016/j.scitotenv. 2020. 140910

D'Aoust PM, Mercier E, Montpetit D, Jia J-J, Alexandrov I, Neault N, Baig AT, Mayne J, Zhang X, Alain T, Langlois M-A, Servos MR, MacKenzie J. Sus. Agric. Sci. Vol. 46, No. 4 (2020) 
M, Figeys D, MacKenzie AE, Graber TE, Delatolla R (2021) Quantitative analysis of SARS-CoV-2 RNA from wastewater solids in communities with low COVID-19 incidence and prevalence. Water Research, 188, 116560. https://doi.org/10.1016/j. watres. 2020. 116560.

El-Ramady H, Abowaly M, Elbehiry F, Omara AE, Elsakhawy T, Mohamed ES, Belal A, Elbasiouny H, Fawzy ZF (2019) Stressful Environments and Sustainable Soil Management: A Case Study of Kafr El-Sheikh, Egypt. Env. Biodiv. Soil Security Vol. 3, 193 - 213. https://doi.org/10.21608/jenvbs. 2019. 17750. 1070 .

El-Ramady H, Alshaal T, El-Henawy A, Abdalla N, Taha HS, Elmahrouk M, Shalaby T, Elsakhawy T, Omara AE, El-Marsafawy S, Elhawat N, Shehata S, Selmar D, Domokos-Szabolcsy É (2018) Environmental Nanoremediation under Changing Climate. Env. Biodiv. Soil Security, Vol. 1,109-128. https://doi.org/10.21608/jenvbs. 2017.1550.1009.

El-Ramady H, Brevik EC, Amer M, Elsakhawy T, Omara A, Elbasiouny H, Elbehiry F, Mosa AA, El-Ghamry AM, Bayoumi Y, Shalaby TA (2020) Soil and Air Pollution in the Era of COVID-19: A Global Issue. Egypt. J. Soil. Sci. 60 (4), https://doi. org/10.21608/ejss.2020.49996.1411.

Elsamadony M, Fujii M, Miura T, Watanabe T (2021) Possible transmission of viruses from contaminated human feces and sewage: Implications for SARSCoV-2. Science of the Total Environment, 755, 142575. https://doi.org/10.1016/j.scitotenv. 2020. 142575 .

ElShazly, A.A.A., Abbas, M.H.H., Farid, I.M., Rizk, M.A., Mohamed, I., Abbas, H.H., Abdelhafez, A.A., Soliman, S.M., Abdel Sabour, M.F. (2019) Feasibility of using natural mineral ores for removing $\mathrm{Cs}$ and $\mathrm{Sr}$ from contaminated water. Ecotoxicology and Environmental Safety, 175, 173180. https://doi.org/10.1016/j.ecoenv.2019.03.044.

Espejo W, Celis JE, Chiang G, Bahamonde P (2020) Environment and COVID-19: Pollutants, impacts, dissemination, management and recommendations for facing future epidemic threats. Science of the Total Environment, 747, 141314. https://doi. org/10.1016/j.scitotenv.2020.141314.

Farkas K, Walker DI, Adriaenssens EM, McDonald JE, Hillary LS, Malham SK, Jones DL (2020) Viral indicators for tracking domestic wastewater contamination in the aquatic environment. Water Research, 181, 115926. https://doi.org/10.1016
Feng B, Xu K, Gu S, Zheng S, Zou Q, Xu Y, Yu L, Lou F, Yu F, Jin T, Li Y, Sheng J, Yen H-L, Zhong Z, Wei J, Chen Y (2021) Multi-route transmission potential of SARS-CoV-2 in healthcare facilities. Journal of Hazardous Materials, 402, 123771. https://doi. org/10.1016/j.jhazmat.2020.123771.

Gautam S (2020) COVID-19: air pollution remains low as people stay at home. Air Quality, Atmosphere \& Health, 13, 853-857.

Gortázar C, de la Fuente J (2020) COVID-19 is likely to impact animal health. Preventive Veterinary Medicine, 180, 105030. https://doi.org/10.1016/j. prevetmed. 2020. 105030.

Groffen T, Rijnders J, van Doorn L, Jorissen C, De Borger SM, Luttikhuis DO, de Deyn L, Covaci A, Bervoets L (2021) Preliminary study on the distribution of metals and persistent organic pollutants (POPs), including perfluoroalkylated acids (PFAS), in the aquatic environment near Morogoro, Tanzania, and the potential health risks for humans. Environmental Research, 192, 110299. https://doi.org/10.1016/j.envres.2020.110299.

Guerrero-Latorre L, Ballesteros I, VillacrésGranda I, Granda MG, Freire-Paspuel B, RíosTouma B (2020) SARS-CoV-2 in river water: Implications in low sanitation countries. Science of the Total Environment, 743, 140832. https://doi. org/10.1016/j. scitotenv. 2020.140832 .

Gwenzi W (2021) Leaving no stone unturned in light of the COVID-19 faecal-oral hypothesis? A water, sanitation and hygiene (WASH) perspective targeting low-income countries. Science of the Total Environment, $\mathbf{7 5 3}, 141751 . \quad \mathrm{https} / / /$ doi. org/10.1016/j.scitotenv. 2020. 141751.

Habib K, Sprecher B, Young SB (2021) COVID-19 impacts on metal supply: How does 2020 differ from previous supply chain disruptions? Resources, Conservation \& Recycling, 165, 105229.

Haris S, Qiu X, Klammler H, Mohamed MMA (2020) The use of micro-nano bubbles in groundwater remediation: A comprehensive review. Groundwater for Sustainable Development, 11, 100463. https://doi.org/10.1016/j.gsd.2020.100463

Hata A, Hara-Yamamura H, Meuchi Y, Imai S, Honda R. (2020) Detection of SARS-CoV-2 in wastewater in Japan during a COVID-19 outbreak. Science of the Total Environment, https://doi.org/10.1016/j. scitotenv. 2020. 143578

He C, Yang L, Cai B, Ruan Q, Hong S, Wang Z 
(2021) Impacts of the COVID-19 event on the NOx emissions of key polluting enterprises in China. Applied Energy, 281, 116042. https://doi. org/10.1016/j.apenergy. 2020.116042

Huang F, Zhang Y, Zhang D, Chen X (2019) Environmental Groundwater Depth for Groundwater-Dependent Terrestrial Ecosystems in Arid/Semiarid Regions: A Review. Int J Environ Res Public Health. 16 (5), 763. https://doi.org/10.3390/ ijerph16050763.

Huang G, Liu L, Liu C, Wang W, Han D (2021) Groundwater pollution of Pearl River Delta. In: Mukherjee A, et al. (Eds.), Global Groundwater: Source, Scarcity, Sustainability, Security, and Solutions. DOI: https://doi.org/10.1016/B978-012-818172-0.00018-9, pp: 251-260. Elsevier Inc.

Ibn-Mohammed T, Mustapha KB, Godsell J, Adamu Z, Babatunde KA, Akintade DD, Acquaye A, Fujii H, Ndiaye MM, Yamoah FA, Koh SCL (2021) A critical analysis of the impacts of COVID-19 on the global economy and ecosystems and opportunities for circular economy strategies. Resources, Conservation \& Recycling, 164, 105169. https:// doi.org/10.1016/j.resconrec. 2020.105169.

Ihsanullah I, Bilal M, Naushad M (2020). Coronavirus 2 (SARS-CoV-2) in water environments: Current status, challenges and research opportunities. Journal of Water Process Engineering, https://doi. org/10.1016/j.jwpe.2020.101735

Ishii E, Watanabe Y, Agusa T, Hosono T, Nakata H (2021). Acesulfame as a suitable sewer tracer on groundwater pollution: A case study before and after the $2016 \mathrm{Mw}$ 7.0 Kumamoto earthquakes. Science of the Total Environment 754, 142409. https://doi.org/10.1016/j.scitotenv.2020.142409

Jia Y (2021). Geogenic-contaminated groundwater in China. In: Mukherjee A, et al. (Ed.), Global Groundwater: Source, Scarcity, Sustainability, Security, and Solutions. DOI: https://doi. org/10.1016/B978-0-12-818172-0.00016-5, pp: 229 - 242. Elsevier Inc.

Juan-Reyes S, Gomez-Oliv LM, Islas-Flores H (2021). COVID-19 in the environment. Chemosphere, 263, 127973.https://doi.org/10.1016/j.chemosphere. 2020. 127973.

Karaouzas I, Kapetanaki N, Mentzafou A, Kanellopoulos TD, Skoulikidis N (2021) Heavy metal contamination status in Greek surface waters: Areview with application and evaluation of pollution indices. Chemosphere, 263, 128192. https://doi. org/10.1016/j.chemosphere.2020.128192.

Kataki S, Chatterjee S, Vairale MG, Sharma S, Dwivedi SK (2021) Concerns and strategies for wastewater treatment during COVID-19 pandemic to stop plausible transmission. Resources, Conservation \& Recycling 164, 105156. https://doi.org/10.1016/j. resconrec. 2020.105156.

Kiani MR, Rahimpour MR (2020) Aquatic/water environment contamination, treatment, and use. In: Alberto Figoli, Yongdan Li and Angelo Basile (Eds.), Current Trends and Future Developments on (Bio-) Membranes DOI: https://doi.org/10.1016/ B978-0-12-816778-6.00010-2, pp: 213-238. Elsevier Inc.

Kitajima M, Ahmed W, Bibby K, Carducci A, Gerba CP, Hamilton KA, Haramoto E, Rose JB (2020) SARS-CoV-2 in wastewater: State of the knowledge and research needs. Science of the Total Environment 739, 139076. https://doi. org/10.1016/j.scitotenv.2020.139076.

Kubicz, J, Lochynski P, Pawerczyk A, Karczewski M (2021) Effects of drought on environmental health risk posed by groundwater contamination. Chemosphere, 263, $128145 . \quad$ https://doi. org/10.1016/j. chemosphere. 2020.128145.

Kumar M, Mazumder P, Mohapatra S, Thakur AK, Dhangar K, Taki K, Mukherjee S, Patel AK, Bhattacharya P, Mohapatra P, Rinklebe J, Kitajima M, Hai FI, Khursheed A, Furumai H, Sonne C, Kuroda K (2020b) A chronicle of SARS-CoV-2: Seasonality, environmental fate, transport, inactivation, and antiviral drug resistance. Journal of Hazardous Materials, https://doi.org/10.1016/j. jhazmat. 2020.124043.

Kumar M, Thakur AK, Mazumder P, Kuroda K, Mohapatra S, Rinklebe J, Ramanathan A, Cetecioglu Z, Jain S, Tyagi VK, Gikas P, Chakraborty S, Islam MT, Ahmad A, Shah AV, Patel AK, Watanabe T, Vithanage M, Bibby K, Kitajima M, Bhattacharya P (2020a) Frontier review on the propensity and repercussion of SARS-CoV-2 migration to aquatic environment. Journal of Hazardous Materials Letters. 1: 100001. https://doi.org/10.1016/j.hazl. 2020. 100001.

Kuroda K, Kobayashi J (2021) Pharmaceuticals, Personal Care Products, and Artificial Sweeteners in Asian Groundwater: A Review. In: M. Kumar et al. (Eds.), Contaminants in Drinking and Wastewater Sources, Springer Transactions in Civil and Environmental Engineering, https://

J. Sus. Agric. Sci. Vol. 46, No. 4 (2020) 
doi.org/10.1007/978-981-15-4599-3_1, pp: 3-36. Springer Nature Singapore Pte Ltd.

La Rosa G, Mancini P, Ferraro GB, Veneri C, Iaconelli M, Bonadonna L, Lucentini L, Suffredini E (2021) SARS-CoV-2 has been circulating in northern Italy since December 2019: Evidence from environmental monitoring. Science of the Total Environment, 750, 141711. https://doi.org/10.1016/j.scitotenv. 2020. 141711 .

Lahrich S, Laghrib F, Farahi A, Bakasse M, Saqrane S, El Mhammedi MA (2021) Review on the contamination of wastewater by COVID-19 virus: Impact and treatment. Science of the Total Environment, 751, 142325. https://doi. org/10.1016/j.scitotenv. 2020. 142325.

Lal R, Brevik EC, Dawson L, Field D, Glaser B, Hartemink AE, Hatano R, Lascelles B, Monger C, Scholten T, Singh BR, Spiegel H, Terribile F, Basile A, Zhang R, Horn R, Kosaki T, Sánchez, LBR (2020) Managing soils for recovering from the COVID-19 pandemic. Soil Systems, 4, 46. https:// doi.org/10.3390/soilsystems4030046.

Langone M, Petta L, Cellamare CM, Ferraris M, Guzzinati R, Mattioli D, Sabia G (2021) SARSCoV-2 in water services: Presence and impacts. Environmental Pollution, 268, 115806. https://doi. org/10.1016/j.envpol.2020.115806.

Li D, Zhai Y, Lei Y, Li J, Teng Y, Lu H, Xia X, Yue W, Yang J (2021) Spatiotemporal evolution of groundwater nitrate nitrogen levels and potential human health risks in the Songnen Plain, Northeast China. Ecotoxicology and Environmental Safety 208, 111524. https://doi.org/10.1016/j.ecoenv. 2020. 111524.

Li Z, Li M, Zhang Z, Li P, Zang Y, Liu X (2020) Antibiotics in aquatic environments of China: A review and meta-analysis. Ecotoxicology and Environmental Safety, 199, 110668. https://doi. org/10.1016/j.ecoenv. 2020.110668.

Liu D, Thompson JR, Carducci A, Bi X (2020) Potential secondary transmission of SARS-CoV-2 via wastewater. Science of the Total Environment, 749, 142358. https://doi.org/10.1016/j.scitotenv.2020. 142358.

Liu J, Zhang L, Lu G, Jiang R, Yan Z, Li Y (2021) Occurrence, toxicity and ecological risk of Bisphenol A analogues in aquatic environment - A review. Ecotoxicology and Environmental Safety, 208, 111481.
Lodder W, Husman AMR (2020) SARS-CoV-2 in wastewater: potential health risk, but also data source. Lancet Gastroenterol. Hepatol. 5 (6), 533-534, https://doi.org/10.1016/S2468-1253(20) 30087-X.

Lokhandwala S, Gautam P (2020) Indirect impact of COVID-19 on environment: A brief study in Indian context. Environmental Research, 188, 109807. https://doi.org/10.1016/j.envres.2020.109807.

Lu T, Zhang Q, Zhang Z, Hu B, Chen J, Chen J, Qian H (2021) Pollutant toxicology with respect to microalgae and cyanobacteria. Journal of Environmental Sciences, https://doi.org/10.1016/j. jes.2020.06.033.

Ma H, Pu S, Liu S, Bai Y, Mandal S, Xing B (2020) Microplastics in aquatic environments: Toxicity to trigger ecological consequences. Environmental Pollution, 261, 114089. https://doi.org/10.1016/j. envpol.2020.114089.

Maheshwari B (2021) Groundwater in Australiaunderstanding the challenges of its sustainable use. In: Mukherjee A, et al. (Eds.), Global Groundwater: Source, Scarcity, Sustainability, Security, and Solutions. DOI: https://doi.org/10.1016/B978-012-818172-0.00028-1, pp: 383-392. Elsevier Inc.

Mallapaty S (2020) How sewage could reveal true scale of coronavirus outbreak. Nature, https://doi. org/10.1038/d41586-020-00973-x.

Martins VV, Zanetti MOB, Pitondo-Silva A, Stehling EG (2014) Aquatic environments polluted with antibiotics and heavy metals: a human health hazard. Environ. Sci. Pollut Res. 21, 5873-5878. https://doi.org/10.1007/s11356-014-2509-4.

Masood N, Batool S, Farooqi A (2021) Groundwater pollution in Pakistan. In: Mukherjee A, et al. (Eds.), Global Groundwater: Source, Scarcity, Sustainability, Security, and Solutions. DOI: https:// doi.org/10.1016/B978-0-12-818172-0.00022-0, pp: 309-322. Elsevier Inc.

Mofijur M, Fattah IM R, Alam MA, Islam ABMS, Ong HC, Rahman SMA, Najafi G, Ahmed SF, Alhaz Uddin M, Mahlia TMI (2021) Impact of COVID-19 on the social, economic, environmental and energy domains: Lessons learnt from a global pandemic. Sustainable Production and Consumption, 26, 343359. https://doi.org/10.1016/j.spc.2020.10.016.

Mohan SV, Hemalatha M, Kopperi H, Ranjith I, Kumar AK (2021) SARS-CoV-2 in environmental perspective: Occurrence, persistence, surveillance, 
inactivation and challenges. Chemical Engineering Journal, 405, 126893. https://doi.org/10.1016/j. cej.2020.126893.

Mohapatra S, Menonc NG, Mohapatra G, Pisharody L, Pattnaik A, Menon NG, Bhukya PL, Srivastava M, Singh M, Barman MK, Gin KY-H, Mukherji S (2020) The novel SARS-CoV-2 pandemic: Possible environmental transmission, detection, persistence and fate during wastewater and water treatment. Science of the Total Environment, https://doi. $\operatorname{org} / 10.1016 /$ j.scitotenv. 2020.142746.

Mostafa MK, Gamal G, Wafiq A (2021) The impact of COVID 19 on air pollution levels and other environmental indicators - A case study of Egypt. Journal of Environmental Management, 277, $111496 . \quad$ https://doi.org/10.1016/j. jenvman.2020.111496.

Mukherjee A, Scanlon BR, Aureli A, Langan S, Guo H, McKenzie AA (2021) Global Groundwater: Source, Scarcity, Sustainability, Security, and Solutions. Elsevier Inc. https://doi.org/10.1016/ C2018-0-03156-4.

Naddeo V, Liu H (2020) Editorial Perspectives: 2019 novel coronavirus (SARS-CoV-2): what is its fate in urban water cycle and how can the water research community respond? Water Res. Technol. Environ. Sci. https://doi.org/10.1039/ d0ew90015j.

Nawale VP, Malpe DB, Marghade D, Yenkie R (2021) Non-carcinogenic health risk assessment with source identification of nitrate and fluoride polluted groundwater of Wardha sub-basin, central India. Ecotoxicology and Environmental Safety, 208, 111548. https://doi.org/10.1016/j.ecoenv. 2020. 111548 .

Núñez-Delgado A (2020) What do we know about the SARS-CoV-2 coronavirus in the environment? Science of the Total Environment 727, 138647.

Pan Z, Liu Q, Jiang R, Li W, Sun X, Lin H, Jiang S, Huang H (2021) Microplastic pollution and ecological risk assessment in an estuarine environment: The Dongshan Bay of China. Chemosphere, 262, 127876. https://doi.org/10.1016/j.chemosphere. 2020. 127876.

Pandey D, Verma S, Verma P, Mahanty B, Dutta K, Daverey A, Arunachalam K (2021) SARS$\mathrm{CoV}-2$ in wastewater: Challenges for developing countries. International Journal of Hygiene and Environmental Health, 231, 113634. https://doi. org/10.1016/j.ijheh. 2020.113634 .
Patni K, Jindal MK (2020) A positive perspective during COVID-19 related to groundwater crisis. Groundwater for Sustainable Development 11, 100420. https://doi.org/10.1016/j.gsd.2020.100420.

Paudel J (2021) Short-run environmental effects of COVID-19: Evidence from forest fires. World Development 137, 105120. https://doi. org/10.1016/j.worlddev.2020.105120.

Postigo C, Ginebreda A, Barbieri MV, Barceló D, Martín-Alonso J, de la Cal A, Boleda MR, Otero N, Carrey R, Solà V, Queralt E, Isla E, Casanovas A, Frances G, de Alda ML (2021) Investigative monitoring of pesticide and nitrogen pollution sources in a complex multi-stressed catchment: The lower Llobregat River basin case study (Barcelona, Spain). Science of the Total Environment, 755, 142377. https://doi.org/10.1016/j.scitotenv.2020. 142377.

Saguti F, Magnil E, Enache L, Churqui MP, Johansson A, Lumley D, Davidsson F, Dotevall L, Mattsson A, Trybala E, Lagging M, Lindh M, Gisslén M, Brezicka T, Nyström K, Norder H (2021) Surveillance of wastewater revealed peaks of SARS$\mathrm{CoV}-2$ preceding those of hospitalized patients with COVID-19. Water Research, 189, 116620. https:// doi.org/10.1016/j.watres.2020.116620.

Sahoo PK, Pontes PRM, Salomao GN, Powell MA, Mittal S, Filho PWMS, Guimaraes JTF (2021) Groundwater management in Brazil: current status and challenges for sustainable utilization. In: Mukherjee A, et al. (Eds.), Global Groundwater: Source, Scarcity, Sustainability, Security, and Solutions. DOI: https://doi.org/10.1016/B978-012-818172-0.00030-X, pp: 409-423. Elsevier Inc.

Saqr M, Wasson B (2020) COVID-19: lost opportunities and lessons for the future. Int. J. Health Sci. 14, 4-6.

Šauer P, Švecová H, Grabicová K, Aydın FG, Mackuロak T, Kodeš V, Blytt LD, Henninge LB, Grabic R, Kroupová HK (2021) Bisphenols emerging in Norwegian and Czech aquatic environments show transthyretin binding potency and other lessstudied endocrine-disrupting activities. Science of the Total Environment, 751, 141801. https://doi. org/10.1016/j.scitotenv.2020.141801.

Selvam S, Jesuraja K, Venkatramanan S, Roy PD, Kumari VJ (2021) Hazardous microplastic characteristics and its role as a vector of heavy metal in groundwater and surface water of coastal south India. Journal of Hazardous Materials, 402, 123786. https://doi.org/10.1016/j.jhazmat. 2020. 
123786.

Siddiqa A, Faisal M (2020) Heavy Metals: Source, Toxicity Mechanisms, Health Effects, Nanotoxicology and Their Bioremediation. In: M. Naeem et al. (eds.), Contaminants in Agriculture, https://doi.org/10.1007/978-3-030-41552-5_6, pp: 117-141. Springer Nature Switzerland AG.

Slije[pevi $\mathrm{N}$, Pilipovic DT, Kerkez Đ, KrDmar D, Milena BeDeli】-Tomin, Beljin J, Dalmacija B (2021) A cost-effective method for immobilization of $\mathrm{Cu}$ and $\mathrm{Ni}$ polluted river sediment with nZVI synthesized from leaf extract. Chemosphere 263, 127816. https://doi.org/10.1016/j.chemosphere. 2020. 127816.

Souza IC, Morozesk M, Mansano AS, Mendes VAS, Azevedo VC, Matsumoto ST, Elliott M, Monferrán MV, Wunderlin DA, Fernandes MN (2021) Atmospheric particulate matter from an industrial area as a source of metal nanoparticle contamination in aquatic ecosystems. / Science of the Total Environment 753, 141976. https://doi. org/10.1016/j.scitotenv.2020.141976.

Steffan JJ, Derby JA, Brevik EC (2020) Soil pathogens that may potentially cause pandemics, including SARS coronaviruses. Current Opinion in Environmental Science \& Health 17, 35-40. https:// doi.org/10.1016/j.coesh.2020.08.005.

Sunkari ED, Korboe HM, Abu M, Kizildeniz T (2021) Sources and routes of SARS-CoV-2 transmission in water systems in Africa: Are there any sustainable remedies? Science of the Total Environment 753, 142298. https://doi.org/10.1016/j.scitotenv. 2020. 142298 .

Tang Y, Liu Y, Chen Y, Zhang W, Zhao J, He S, Yang C, Zhang T, Tang C, Zhang C, Yang Z (2020)A review: Research progress on microplastic pollutants in aquatic environments. Science of the Total Environment, https://doi.org/10.1016/j.scitotenv. 2020. 142572 .

Torres-Salinas D (2020) Daily growth rate of scientific production on COVID-19: Analysis in databases and repositories in open access. El Prof. Inf. 29 (2) https://doi.org/10.3145/epi.2020.mar.15. (in Spanish, cited from Casado-Aranda et al. 2020).

Tracy JW, Guo A, Liang K, Bartram J, Fisher M (2020) Sources of and Solutions to Toxic Metal and Metalloid Contamination in Small Rural Drinking Water Systems: A Rapid Review. Int J Environ Res Public Health. 17(19), 7076. https://doi. org/10.3390/ijerph17197076.
Turan NB, Erkan HS, Engin GO, Bilgili MS (2019). Nanoparticles in the aquatic environment: Usage, properties, transformation and toxicity-A review. Process Safety and Environmental Protection 130, 238-249. https://doi.org/10.1016/j.psep.2019. 08.014 .

Urban RC, Nakada LYK (2021) COVID-19 pandemic: Solid waste and environmental impacts in Brazil. Science of the Total Environment 755, 142471. https://doi.org/10.1016/j.scitotenv. 2020.142471.

Verma M (2020) Ecotoxicology of Heavy Metals: Sources, Effects and Toxicity. In: R. A. Bhat et al. (eds.), Bioremediation and Biotechnology, Vol 2, Springer Nature Switzerland AG, https://doi. org/10.1007/978-3-030-40333-1_2, pp: 13-23.

Wang Q, Su M (2020) A preliminary assessment of the impact of COVID-19 on environment - A case study of China. Science of the Total Environment 728, 138915. https://doi.org/10.1016/j.scitotenv. 2020. 138915.

Wang X, Bolan N, Tsang DCW, Sarkar B, Bradney L, Li Y (2021) A review of microplastics aggregation in aquatic environment: Influence factors, analytical methods, and environmental implications. Journal of Hazardous Materials 402, 123496. https://doi. org/10.1016/j.jhazmat. 2020.123496.

Wanner P (2021). Plastic in agricultural soils e A global risk for groundwater systems and drinking water supplies? A review. Chemosphere 264, 128453. https://doi.org/10.1016/j.chemosphere.2020. 128453.

Werth A, Gravino P, Prevedello G (2021) Impact analysis of COVID-19 responses on energy grid dynamics in Europe. Applied Energy 281, 116045. https://doi.org/10.1016/j.apenergy.2020.116045.

Westhaus S, Weber F-A, Schiwy S, Linnemann V, Brinkmann M, Widera M, Greve C, Janke A, Hollert H, Wintgens T, Ciesek S (2021) Detection of SARS-CoV-2 in raw and treated wastewater in Germany - Suitability for COVID-19 surveillance and potential transmission risks. Science of the Total Environment 751, 141750. https://doi. org/10.1016/j. scitotenv.2020.141750.

Workie E, Mackolil J, Nyika J, Ramadas S (2020) Deciphering the impact of COVID-19 pandemic on food security, agriculture, and livelihoods: A review of the evidence from developing countries. Current Research in Environmental Sustainability 2, 100014. http://dx.doi.org/10.1016/j.crsust. 2020 100014. 
Wu F, Xiao A, Zhang J, Gu X, Lee WL, Kauffman K, Hanage W, Matus M, Ghaeli N, Endo N, Duvallet C, Moniz K, Erickson T, Chai P, Thompson J, Alm E (2020) SARS-CoV-2 titers in wastewater are higher than expected from clinically confirmed cases. MedRxiv, https://doi.org/10.1101/ 2020.04.05. 20051540 .

Wu J, Bian J, Wan H, Ma Y, Sun X (2021) Health risk assessment of groundwater nitrogen pollution in Songnen Plain. Ecotoxicology and Environmental Safety, 207, 111245. https://doi.org/10.1016/j. ecoenv. 2020. 111245.

Xu L, Zhang H, Xiong P, Zhu Q, Liao C, Jiang G (2021) Occurrence, fate, and risk assessment of typical tetracycline antibiotics in the aquatic environment: A review. / Science of the Total Environment, 753, 141975. https://doi.org/10.1016/j.scitotenv. 2020. 141975.

Yadav A, Rene ER, Mandal MK, Dubey KK (2021) Threat and sustainable technological solution for antineoplastic drugs pollution: Review on a persisting global issue. Chemosphere, 263, 128285. https://doi.org/10.1016/j.chemosphere.2020. 128285 .

Yan H, Li Q, Yuan Z, Jin S, Jing M (2019) Research Progress of Mercury Bioaccumulation in the Aquatic Food Chain, China: A Review. Bulletin of Environmental Contamination and Toxicology, 102, 612-620 https://doi.org/10.1007/s00128-01902629-7.

Yang Y, Ye S, Zhang C, Zeng G, Tan X, Song B, Zhang P, Yang H, Li M, Chen Q (2021) Application of biochar for the remediation of polluted sediments. Journal of Hazardous Materials, 404, 124052. https://doi.org/10.1016/j.jhazmat.2020.124052.

Yeung KWY, Zhou G-J, Hilscherová K, Giesy JP, Leung KMY (2020) Current understanding of potential ecological risks of retinoic acids and their metabolites in aquatic environments. Environment International, 136, 105464. https:// doi.org/10.1016/j.envint. 2020.105464.
Yunus AP, Masago Y, Hijioka Y (2020) COVID-19 and surface water quality: Improved lake water quality during the lockdown. Science of the Total Environment, 731, 139012. https://doi. org/10.1016/j.scitotenv.2020.139012.

Zaneti RN, Girardi V, Spilki FR, Mena K, Westphalen APC, Colares ERC, Pozzebon AG, Etchepare RG (2021) Quantitative microbial risk assessment of SARS-CoV-2 for workers in wastewater treatment plants. Science of the Total Environment, 754, 142163. https://doi.org/10.1016/j.scitotenv. 2020. 142163.

Zhao N, F You (2021) Food-energy-water-waste nexus systems optimization for New York State under the COVID-19 pandemic to alleviate health and environmental concerns. Applied Energy, 282, 116181. https://doi.org/10.1016/j. apenergy.2020.116181.

Zhou J, Li S, Liang X, Feng X, Wang T, Li Z, Zhu L (2021) First report on the sources, vertical distribution and human health risks of legacy and novel per- and polyfluoroalkyl substances in groundwater from the Loess Plateau, China. Journal of Hazardous Materials, 404, 124134. https://doi.org/10.1016/j.jhazmat.2020.124134.

Zhou P, Yang XL, Wang XG, Hu B, Zhang L, Zhang W, Si HR, Zhu Y, Li B, Huang CL, Chen HD, Chen J, Luo Y, Guo H, Di Jiang R, Liu MQ, Chen Y, Shen XR, Wang X, Zheng XS, Zhao K, Chen QJ, Deng F, Liu LL, Yan B, Zhan FX, Wang YY, Xiao GF, Shi ZL (2020) A pneumonia outbreak associated with a new coronavirus of probable bat origin. Nature. 579, 270-273, https://doi.org/10.1038/s41586-0202012-7.

Zhou R, Lu G, Yan Z, Jiang R, Bao X, Lu P (2020) A review of the influences of microplastics on toxicity and transgenerational effects of pharmaceutical and personal care products in aquatic environment. Science of the Total Environment, 732, 139222. https://doi.org/10.1016/j.scitotenv.2020.139222. 